\title{
NOTE ON ABBREVIATIONS AND REFERENCES
}

Full bibliographical details of all sources are given in the bibliography on pp. 507-534. References throughout the footnotes are by abbreviated title, with authors' or editors' names, where relevant.

The following abbreviations are also used to refer to sources:

Ann. Wint. "Annales monasterii de Wintona". In Annales monastici, vol. $3^{6}$, part 1

AO Anselmi opera: S. Anselmi Cantuariensis Archiepiscopi opera omnia. Ed. Francis S. Schmitt. 6 vols. Stuttgart, 1946-1961. Repr. 1968

ASC Anglo-Saxon Chronicle. Ed. Dorothy Whitelock. New Jersey, 1961

Bayeux, Antiquus cartularius baiocensis (Livre noir). Ed. F. Liebermann.

Livre noir Strasbourg, 1879

$\mathrm{BL}$

British Library

CDF Calendar of Documents Preserved in France, Illustrative of the History of Great Britain and Ireland. Ed. J. H. Round. Vol. 1, AD 918-1206. London, 1889

Chron. Ab. Chronicon monasterii de Abingdon. Ed. Joseph Stevenson. Rolls Series, vol. 2. London, $185^{8}$

Chron. Battle Chronicle of Battle Abbey. Ed. Eleanor Searle. Oxford, 1980

CMH Cambridge Medieval History. Vol. 5: The Contest of Empire and Papacy. Ed. J. R. Tanner, C. W. Previté-Orton, Z. N. Brooke. Cambridge, 1929-1967

CP Complete Peerage of England, Scotland, Ireland, Great Britain and the United Kingdom. New edn, rev. and enl. Ed. Vicary Gibbs. 13 vols in 14. London, 1910-1959

CUL Cambridge University Library

DB

DNB Dictionary of National Biography. London, 1891

Eadmer, Eadmer, Historia novorum in Anglia. Ed. Martin Rule. Rolls Series, HN vol. 81. London, 1884

EHD English Historical Documents. Ed. and trans. David C. Douglas and George Greenway. Vol. 2: 1066-1189. 2nd edn, New York, 1981

ep./epp. epistle/epistles

EYC Early Yorkshire Charters. Ed. William Farrer and C. T. Clay. 12 vols. Edinburgh, 1914-1965

EYF Early Yorkshire Families. Ed. Charles Travis Clay. Leeds, 1973

Farrer, Itin. Outline Itinerary of King Henry the First. Ed. William Farrer. Oxford, 1920

FW Florence of Worcester, Chronicon ex chronicis. Ed. B. Thorpe. 2 vols. London, $1848-1849$ 
$G C$

GND

$G P$

GR

HF

$\mathrm{HH}$

$H N$

JW

Liber de

Hyda

$M G H$

$M M I$

NI

OV

PL

$P_{3}{ }^{I}$

RBE

RRAN

RS

RT, Chron.

SD

$V C H$

$\mathrm{WM}$

$\mathrm{WM}, G P$

WM, GR

$\mathrm{WM}, H N$
Gallia Christiana in provincias ecclesiasticas distributa; qua series et historia archiepiscoporum, episcoporum, et abbatum Franciae vicinarumque ditionum ab origine ecclesiarum ad nostra tempora, deducitur et probatur ex authenticis documentis ad calcem appositis. 16 vols. Paris, $1715^{-1865}$. Reprint 1970

Gesta normannorum ducum of William of Jumièges, Orderic Vitalis and Robert of Torigni. Ed. and trans. Elisabeth M. C. van Houts. 2 vols. Oxford, 1992-1995

see William of Malmesbury

see William of Malmesbury

Recueil des historiens des Gaules et de la France. Ed. Martin Bouquet. 24 vols in 25. Vol. 15: Reigns of Philip I, Louis VI, Louis VII. Repr.

Farnborough, 1967-1968

Henry of Huntingdon, Historia Anglorum. Ed. Diana Greenway. Oxford, 1996

see Eadmer and William of Malmesbury

John of Worcester, Chronicle. Ed. J. R. H. Weaver. Oxford, 1908

Liber monasterii de Hyda. Ed. Edward Edwards. Rolls Series, vol. 45 . London, 1866

Monumenta Germaniae historica. Scriptores rerum Germanicarum. 13 vols. Berlin, 1955-198o

C. Warren Hollister, Monarchy, Magnates, and Institutions in the Anglo-Norman World. London, 1986

C. H. Haskins. Norman Institutions. Cambridge, Mass., 1918

Orderic Vitalis, Historia ecclesiastica/Ecclesiastical History. Ed. and trans. Marjorie Chibnall. 6 vols. Oxford, 1969-1980

Patrologia cursus completus. Series latina. Ed. J-P. Migne. 221 vols. Paris, 1844-1864. Repr. 1958-

Pipe Roll of Henry I, Michaelmas I з зо. Ed. Joseph Hunter. Rev. edn, London, 1929

Red Book of the Exchequer. Ed. Hubert Hall. Rolls Series, vol. 99. London, 1896

Regesta regum anglo-normannorum. Vol. 1: Regesta Willelmi Rufi, ed. H. W. C. Davis. Vol. 2: Regesta Henrici Primi, ed. C. Johnson and H. A. Cronne. Vol. 3: Regesta Regis Stephani ac Mathildis imperatricis ac Gaufredi et Henrici ducum normannorum, II35-I154, ed. H. A. Cronne and R. H. C. Davis. Oxford, 1913-1969

Rolls Series: Rerum Britannicarum medii aevi scriptores. 99 vols. London, 1858-1911. Reprint, 1964-1965

Robert of Torigni, Chronique. Ed. Léopold Delisle. 2 vols. Rouen, 1872-1873

Symeon of Durham, Historia ecclesiae dunelmensis, in Symeonis monachi opera omnia. Ed. Thomas Arnold. Rolls Series, vol. 75, part 1. London, 1882-1885

Victoria County History

William of Malmesbury

William of Malmesbury, Gestis pontificum anglorum. Ed. N. E. S. A. Hamilton. Rolls Series, vol. 52. London, 1870

William of Malmesbury, Gesta regum anglorum. Ed. and trans. R. A. B. Mynors; completed by R. M. Thomson and M. Winterbottom. Oxford and New York, 1998

William of Malmesbury, Historia novella. Ed. and trans. K. R. Potter. London, 1955 